\title{
IQTISHODUNA
}

Vol. 17 (1), 2021

P-ISSN: 1829-524X, E-ISSN: 2614-3437

\section{Analisis Tingkat Kreativitas Wirausaha Mahasiswa Melalui Program Komunitas Entrepreneur}

\author{
Esy Nur Aisyah \\ UIN Maulana Malik Ibrahim Malang, Indonesia \\ E-mail: esynuraisyah@pbs.uin-malang.ac.id
}

\begin{abstract}
This research is motivated by the Entrepreneur Community Program's existence as support for entrepreneurship courses in the Islamic Banking Department, Faculty of Economics, UIN Maulana Malik Ibrahim Malang to produce graduates who have high selling value, entrepreneurship, and creativity to be able to compete. The learning approach in the program is Project-Based Learning. This study aimed to analyze the level of student creativity before and after participating in the Entrepreneur Community Program. The number of participants was 75 students from the concentration of entrepreneurs in the observation year. Data analysis used nonparametric statistics with Paired-Samples T-Test in testing the creativity of the respondent level before and after treatment and assessing the creativity level of students based on the results of the creativity score generated from the total score filled by respondents divided by the total maximum score of each statement and outlined in the form proportion. The breakthrough research results showed that there were differences in the level of students before and after treatment. The treatment here means that students take part in the entrepreneurial community program with Project-Based Learning. They increased student creativity from $70 \%$ to $83 \%$. The level of student creativity before treatment was in the medium category. Moreover, after getting the treatment is in the high category. Thus, project-based learning through the Entrepreneur Community Program in Islamic Banking Department, Faculty of Economics can increase student entrepreneurial creativity.
\end{abstract}

Keywords: Entrepreneurship, Community, Creativity, Students, Project-Based Learning

\begin{abstract}
Abstrak: Penelitian ini dilatarbelakangi oleh adanya Program Komunitas Entrepreneur sebagai penunjang perkuliahan kewirausahaan di Prodi Perbankan Syariah Fakultas Ekonomi UIN Maulana Malik Ibrahim Malang dalam rangka menghasilkan lulusan yang memiliki nilai jual, entreprenurship, dan kreativitas yang tinggi untuk mampu bersaing. Pendekatan pembelajaran di dalam program tersebut adalah Project-Based Learning. Sehingga tujuan
\end{abstract}


dari penelitian adalah menganalisis tingkat kreativitas mahasiswa sebelum dan sesudah mengikuti Program Komunitas Entreprenur. Jumlah partisipan sebanyak 75 mahasiswa dari konsentrasi entrepreneur di tahun pengamatan. Analisis data menggunakan statistik nonparametric dengan uji Paired-Samples T-Test dalam menguji perbedaan tingkat kreativitas responden sebelum dan sesudah perlakukan dan menilai tingkat kreativitas mahasiswa berdasarkan hasil skor kreativitas yang dihasilkan dari jumlah skor yang diisi responden dibagi dengan total skor maksimum dari setiap pernyataan dan dituangkan dalam bentuk persentase. Hasil penelitian memperlihatkan bahwa ada perbedaan tingkat kreativitas mahasiswa sebelum dan sesudah mendapatkan perlakuan. Perlakuan di sini maksudnya adalah mahasiswa mengukuti program komunitas entrepreuner dengan Project-Based Learning. Terdapat peningkatan kreativitas mahasiswa dari 70\% menjadi 83\%. Tingkat kreativitas mahasiswa sebelum mendapatkan perlakuan dalam kategori sedang. Dan setelah mendapatkan perlakukan yaitu berada dalam kategori tinggi. Dengan demikian, Pembelajaran berbasis proyek melalui Program Komunitas Entrepreneur di Prodi Perbankan Syariah Fakultas Ekonomi mampu meningkatkan kreativitas wirausaha mahasiswa.

Kata Kunci: Entrepreneurship, Komunitas, Kreativitas, Mahasiswa, ProjectBased Learning

| Draft awal Juni 2020 |Diterima Maret 2021 | Terbit April 2021 |

| DOI: http: //dx.doi.org/10.18860/iq.v17i1.7949

\section{Cara mencitasi:}

Aisyah, E.N. (2021). Analisis Tingkat Kreativitas Wirausaha Mahasiswa Melalui Program Komunitas Entrepreneur. Iqtishoduna, 17(1), 49-64.

\section{Pendahuluan}

Menghadapi revolusi industri dengan tingkat persaingan yang tinggi di saat ini, para lulusan dari perguruan tinggi dituntut memiliki pengetahuan akademik, keterampilan berfikir, manajemen keterampilan, dan keterampilan berkomunikasi (Hasanah \& Ratumbuysang, 2017). Sebuah sinergitas akan tampak melalui bagaimana lulusan mampu menemukan solusi dengan cepat dalam setiap masalah yang dialaminya. Sikap dan cara berfikir mereka diharapkan bersifat membangun dan pragmatis yakni bertindak kreatif. Kemampuan ini pada dasarnya dapat dilaksanakan oleh setiap orang, terlebih apabila sudah belajar di Perguruan Tinggi. Secara definitif, kreativitas adalah wujud kesatuan yang terdiri dari tiga unsur utama yang ada pada diri manusia, yakni: pikiran, perasaan, dan

50 | IQTISHODUNA Vol. 17 (1), 2021

http://ejournal.uin-malang.ac.id/index.php/ekonomi 
keterampilan (Hasanah \& Ratumbuysang, 2017). Di dalam unsur pikiran terdapat fantasi, rekognisi dan logika. Unsur perasaan terdapat afeksi, artistik dan penyerasian. Dan unsur keterampilan terdapat talenta, kerja tubuh dan pengalaman. Oleh karena itu, supaya mahasiswa mampu mencapai pada level kreatif, ketiga unsur tersebut diupayakan supaya optimal di dalam perkuliahan kewirauahaan dan program penunjang lainnya (Hasanah \& Ratumbuysang, 2017).

Terdapat banyak model dan media yang dapat dikreasikan di dalam mendidik, membentuk keterampilan, serta mengembangkan kreativitas mahasiswa dalam berwirausaha yaitu dengan pendekatan brainstorming (Harinti \& Margaretha, 2014; Margaretha et al., 2012), Program Kreativitas Mahasiswa (Hasanah \& Ratumbuysang, 2017), pendidikan berbasis technopreneurship (Sumarno, dkk, 2018), dan Program Kemitraan dengan pelaku UMKM (Setyawati, 2019). Dalam penelitian ini, membentuk keterampilan kreativitas mahasiswa melalui Program Komunitas Entrepreneur yang menerapkan Project-Based Learning (Sari \& Angreni, 2018). erdapat 4 tahapan di dalam alur pengembangan model pembelajaran berbasis proyek yaitu, 1) Panetapan, 2) Rancangan, 3) Pengembangan, dan 4) Penyebaran. Di mana alur ini terintegrasi dengan berbagai program pembelajaran di Prodi Perbankan Syariah baik yang termuat di dalam kurikukum dalam bentuk matakuliah ataupun di program Komunitas Mahasiswa (Aisyah \& Solekah, 2018).

Prodi Perbankan Syariah Fakultas Ekonomi UIN Maulana Malik Ibrahim terdapat sebuah program komunitas, yaitu komunitas enterpreneur yang manjadi organisasi bagi mahasiswa yang berminat di dunia kewirausahaan. Beberapa program di komunitas ini terhubung dengan muatan materi di matakuliah kewirausahaan dan anggota mendapatkan mentoring secara mendalam dari dosen dengan model pembelajaran berbasis proyek (ProjectBased Learning.). Jadi, riset ini bertujuan untuk mengetahui tingkat kreativitas mahasiswa sebelum dan sesudah bergabung di Program Komunitas Entrepreneur.

\section{Kajian Pustaka}

\section{Kreativitas, Entrepreneurship, dan Komunitas}

Kreativitas adalah kompetensi seseorang dalam menciptakan objek yang bercirikan adanya sebuah keaslinan (orisinilitas) dan berekspresi 
secara imajinatif (Pamilu, 2007). Kemudian Johnson (2007) menyatakan bahwa kebiasan dari pikiran principle dan diasah dengan memperhatikan naluri/insting, menghidupkan fantasi, menyampaikan peluang, membuka sudut pandang yang mengagumkan dan membangkitka ide-ide mengejutkan merupakan definisi dari berfikir kreatif. Jadi, untuk berpikir kreatif memerlukan sebuah ketekunan, kedisiplinan, dan kensentrasi secara penuh di dalam aktivitas mental, seperti:

1) Mengutarakan persoalan.

2) Meninjau atas kabar baru serta gagasan/ide yang aneh dengan pikiran terbuka.

3) Membentuk implikasi diantara perihal yang berbeda.

4) Mensinkronisasi segala sesuatu yang bebas.

5) Mengimplementasikan daya khayal di setiap kondisi guna menghasilkan suatu hal yang berbeda dan baru.

6) Mengindahkan naluri/insting.

Ananta \& Farid (2014) membuktikan bahwa kreativitas memiliki dampak signifikan terhadap minat berwirausaha. Menurut Kurniati (2015), terdapat empat tema penting dalam definisi kewirausahaan, yaitu:

1. The pursue of oppurtunities, bahwa kewirausahaan kegiatan menemukan peluang dalam usaha dengan memperhatikan berbagai perubahan lingkungan.

2. Creativity and innovation, bahwa kewirausahaan merupakan pengembangan ide-ide baru untuk melakukan perubahan dari bisnis.

3. Value added, bahwa kewirausahaan merupakan usaha untuk memberikan nilai tambah atas setiap kebutuhan masyarakat.

4. Growth, bahwa kewirausahaan merupakan kegiatan yang bertahap. Mulai dari tahap perkenalan hingga tahap inovasi.

Dalam rangka mendukung dan mengembangkan bisnis, cukup banyak komunitas-komunitas yang didirikan oleh sekelompok orang di bidang kewirausahaan. Secara definisi, Kertajaya (2008) mengartikan komunitas merupakan kumpulan orang yang memiliki kesamaan ketertarikan dan rasa kepedulian antara satu dengan yang lainnya, sehingga tercipta sebuah hubungan pribadi yang erat antar sesama anggota komunitas tersebut. Terdapat 4 faktor yang membetuk kesamaan minat menurut Delobelle (2008), yakni:

a. Adanya komunikasi dan rasa ingin untuk berbagi.

52| IQTISHODUNA Vol. 17 (1), 2021

http://ejournal.uin-malang.ac.id/index.php/ekonomi 
b. Adanya tempat untuk bertemu.

c. Memiliki ritual atau kebiasaan.

d. Memiliki kemampuan untuk mempengaruhi.

\section{Project Based Learning}

Project-Based Learning adalah inovasi pembelajaran dengan memusatkan pada peserta didik (student centered) dan memposisikan pendidik menjadi fasilitator dan motivator, selain itu peserta didik belajar dengan mandiri sesuai desain belajar yang dibuatnya sendiri (Al-Tabany, 2014). Berdasarkan definisi tersebut pembelajaran dengan Model ProjectBased Learning (PjBL) adalah metode belajar yang menyertakan adanya proyek di dalam proses edukasi. Adapun karakteristik model pembelajaran berbasis proyek adalah sebagai berikut (Aqib, 2013):

1. Adanya masalah yang tanpa ada solusi yang disiapkan sebelumnya.

2. Perancang proses di dalam pembelajaran untuk mencapai hasil dilakukan olej Peserta didik.

3. Pengumpulan dan pengelolaan informasi menjadi tanggungjawab Peserta didik.

4. Adanya evaluasi secara berkelanjutan.

5. Peserta didik disiplin dalam hal meninjau kembali atas apa yang sudah dikerjakan.

6. Output kegiatan berupa produk dan menganalisis kualitas produk tersebut.

7. Memiliki kelas dengan suasana yang memberi toleransi kesalahan dan perubahan.

Untuk mengetahui pengembangan kreativitas wirausaha mahasiswa dengan menggunakan metode pembelajaran berbasis proyek di dalam Program Komunitas Entrepreneur, mahasiswa sebagai raw input akan dinilai tingkat kreativitasnya sebelum diberi perlakuan (sebelum bergabung di Program Komunitas Entrepreneur) dan sesudah mendapatkan perlakukan (sesudah bergabung di Program Komunitas Entrepreneur). Pengembangan kreativitas menggunakan metode Project-Based Learning di dalam Program Komunitas Entrepreneur dapat dilihat pada Gambar 1. 


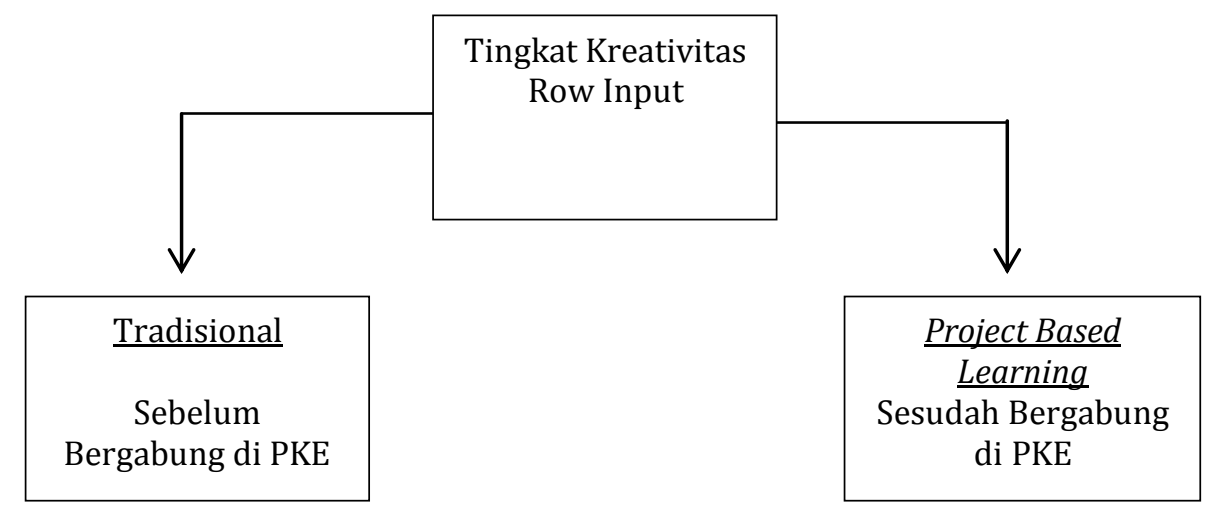

Gambar 1. Kerangka Konsep

\section{Hipotesis}

Berdasarkan penjelasan tentang kreativitas dan metode Project-Based Learning baik secara teoritis dan temuan hasil penelitian, maka hipotesis penelitian sebagai berikut:

H1: Mahasiswa yang belum mendapatkan perlakuan Project-Based Learning melalui Program Komunitas Entrepreneur memiliki tingkat kreatifitas yang berbeda dibandingkan setelah mendapatkan perlakuan.

H2: Ada peningkatan kreativitas mahasiswa setelah mendapatkan perlakuan Project-Based Learning melalui Program Komunitas Entrepreneur.

\section{Metodologi Penelitian}

Penelitian ini merupakan jenis penelitian kuantitatif, dimana memiliki pengukuran dan perhitungan dengan rumus dalam data numerik, dengan proses penelitian yang dimulai dari hipotesis, analisis data dan kesimpulan data. Data kuantitatif dalam penelitian ini adalah data pengukuran kreativitas mahasiswa yang nantinya tertuang di dalam tabel dan klasifikasi dari setiap komponennya. Objek penelitian ini yaitu Mahasiswa konsentrasi Entrepreneur di Prodi Perbankan Syariah Fakultas Ekonomi UIN Maulana Malik Ibrahim Malang dari tahun angkatan 2016/2017 dan 2017/2018. Populasi sebanyak 75 mahasiswa konsentrasi entrepreneur dan seluruhnya menjadi partisipan dalam riset ini. Dan Analisis data menggunakan statistik nonparametric dengan uji Paired-Samples T-Test dalam membandingkan tingkat kreativitas responden sebelum dan sesudah perlakuan dan menilai tingkat kreativitas responden berdasarkan hasil skor kreativitas yang

54| IQTISHODUNA Vol. 17 (1), 2021

http://ejournal.uin-malang.ac.id/index.php/ekonomi 
dihasilkan dari jumlah skor yang diisi responden dibagi dengan total skor maksimum dari setiap pernyataan dan dituangkan dalam bentuk persentase.

Tabel 1. Kriteria Nilai Kreativitas

\begin{tabular}{cll}
\hline No & Interval Nilai Skor / Pencapaian \% & \multicolumn{1}{c}{ Hasil } \\
\hline 1 & $60-79$ & Sedang \\
2 & $80-90$ & Tinggi \\
3 & Lebih dari 90 & Sangat Tinggi \\
\hline
\end{tabular}

Instrumen penilaian kreatifitas menggunaka indikator dari personal tes yang yang dibuat oleh Kasali dkk (2010) di dalam buku Modul Kewirausahaan Bank Mandiri. Personal test tersebut memiliki 75 item pernyataan dan diukur menggunakan skala Likert. Menurut Riduwan \& Kuncoro (2008) skala Likert dapat mengukur sikap, pendapat, dan persepsi seseorang ke dalam lima poin skala interval. Lima poin skala tersebut yaitu 1 = sangat tidak setuju, 2 = tidak setuju, 3 = ragu-ragu, $4=$ setuju, dan $5=$ sangat setuju.

\section{Hasil Penelitian dan Pembahasan}

Tabel 2. Deskripsi Responden

\begin{tabular}{|c|c|c|c|c|c|}
\hline & & quency & Percent & Valid Percent & $\begin{array}{c}\text { Cumulative } \\
\text { Percent }\end{array}$ \\
\hline \multirow{3}{*}{ Gender } & Laki-laki & 36 & 48,0 & 48,0 & 48,0 \\
\hline & Perempuan & 39 & 52,0 & 52,0 & 100,0 \\
\hline & Total & 75 & 100,0 & 100,0 & \\
\hline \multirow{4}{*}{ Usia } & $20-21$ & 56 & 74,7 & 74,7 & 74,7 \\
\hline & $22-23$ & 18 & 24,0 & 24,0 & 98,7 \\
\hline & $24-25$ & 1 & 1,3 & 1,3 & 100,0 \\
\hline & Total & 75 & 100,0 & 100,0 & \\
\hline \multirow{3}{*}{$\begin{array}{l}\text { Daerah } \\
\text { asal }\end{array}$} & Jawa & 61 & 81,3 & 81,3 & 81,3 \\
\hline & Non Jawa & 14 & 18,7 & 18,7 & 100,0 \\
\hline & Total & 75 & 100,0 & 100,0 & \\
\hline \multirow{3}{*}{$\begin{array}{l}\text { Profesi } \\
\text { Ortu }\end{array}$} & Wirausaha & 32 & 42,7 & 42,7 & 42,7 \\
\hline & Non Wirausaha & 43 & 57,3 & 57,3 & 100,0 \\
\hline & Total & 75 & 100,0 & 100,0 & \\
\hline
\end{tabular}

Berdasarkan Tabel 2, jumlah responden dengan jenis kelamin laki-laki sebanyak 36 mahasiswa dan dengan jenis kelamin perempuan sebanyak 39 mahasiswa. Dengan demikian berdasarkan jenis kelamin, responden dalam 
Esy Nur Aisyah

penelitian adalah lebih banyak berjenis kelamin perempuan. Jumlah responden di rentang usia 20 - 21 tahun sebanyak 56 mahasiswa, di rentang usia 22 - 23 tahun sebanyak 18 mahasiswa dan rentang usia 24 - 25 tahun sebanyak 1 mahasiswa. Dengan demikian berdasarkan usia, responden dalam penelitian adalah lebih banyak di rentang usia 20-21 tahun, tepatnya berdasarkan data asli (tanpa rentang) adalah di usia 21 tahun.

Berdasarkan Tabel 2, jumlah responden dengan asal daerah dari Jawa sebanyak 61 mahasiswa dan dengan asal daerah bukan dari pulau Jawa adalah sebanyak 14 mahasiswa. Dengan demikian berdasarkan asal daerah, responden dalam penelitian adalah lebih banyak berasal dari pulau Jawa. Jumlah responden dengan dengan profesi orang tua sebagai wirauswahan sebanyak 32 mahasiswa dan dengan dengan profesi orang tua sebagai nonwirausawahan adalah sebanyak 43 mahasiswa. Dengan demikian berdasarkan profesi orang tua, responden dalam penelitian adalah lebih banyak berasal dari yang orang tuanya memiliki profesi nonwirausahawan.

Tabel 3. Deskripsi Responden Berdasarkan Kreatif_Sebelum Perlakuan

\begin{tabular}{llrrrr}
\hline & & Frequency & Percent & Valid Percent & Cumulative Percent \\
& & & & & \\
\hline \multirow{3}{*}{ Valid } & 3 & 38 & 50,7 & 50,7 & 50,7 \\
& 4 & 37 & 49,3 & 49,3 & 100,0 \\
& Total & 75 & 100,0 & 100,0 & \\
\hline
\end{tabular}

Berdasarkan Tabel 3, nilai skala terendah yang dipilih responden adalah skala 3 dan skala tertinggi sebesar skala 4 . Kemudian jumlah responden dengan memilih nilai skala 3 sebanyak 38 mahasiswa dan memilih skala 4 sebanyak 37 mahasiswa. Dengan demikian berdasarkan skala kreativitas sebelum perlakuan, responden dalam penelitian adalah lebih banyak memilih angka 3.

Tabel 4. Deskripsi Responden Berdasarkan Kreatif_Sesudah Perlakuan

\begin{tabular}{llrrrr}
\hline & & Frequency & Percent & Valid Percent & Cumulative Percent \\
& & & & & 85,3 \\
\multirow{2}{*}{ Valid } & 4 & 64 & 85,3 & 85,3 & 100,0 \\
& 5 & 11 & 14,7 & 14,7 & \\
& Total & 75 & 100,0 & 100,0 & \\
\hline
\end{tabular}

56| IQTISHODUNA Vol. 17 (1), 2021

http://ejournal.uin-malang.ac.id/index.php/ekonomi 
Berdasarkan Tabel 4, nilai skala terendah yang dipilih responden adalah skala 4 dan skala tertinggi sebesar skala 5. Kemudian jumlah responden dengan memilih nilai skala 4 sebanyak 64 mahasiswa dan memilih skala 5 sebanyak 11 mahasiswa. Dengan demikian berdasarkan skala kreativitas setelah perlakuan, responden dalam penelitian adalah lebih banyak memilih angka 4.

Untuk menguji perbedaan tingkat kreatifitas mahasiswa di hipotesis pertama adalah dengan menggunakan uji Paired-Samples T-Test, dengan hasil seperti pada Tabel 5.

Tabel 5. Nilai Paired Samples Test

\begin{tabular}{|c|c|c|c|c|c|c|c|c|c|}
\hline & \multicolumn{5}{|c|}{ Paired Differences } & \multirow[t]{2}{*}{$t$} & \multirow[t]{2}{*}{$\mathrm{df}$} & \multirow[t]{2}{*}{ Sig. } \\
\hline & & Mean & $\begin{array}{l}\text { Std. } \\
\text { Devia } \\
\text { tion }\end{array}$ & $\begin{array}{l}\text { Std. } \\
\text { Error } \\
\text { Mean }\end{array}$ & \multicolumn{2}{|c|}{$\begin{array}{l}\text { 95\% Confidence } \\
\text { Interval of the } \\
\text { Difference }\end{array}$} & & & \\
\hline \multirow{3}{*}{$\begin{array}{c}\text { Pair } \\
1\end{array}$} & Kreatif_ & & & & Lower & Upper & & & \\
\hline & Sebelum & & & & & & & & \\
\hline & $\begin{array}{l}\text { Kreatif } \\
\text { Sesudah }\end{array}$ &,- 653 & 647 & ,075 & -802 &,- 504 & $-8,744$ & 74 & ,000 \\
\hline
\end{tabular}

Berdasarkan Tabel 5, nilai signifikasi pair 1 lebih kecil dari 0.025 artinya terdapat perbedaan tingkat kreativitas sebelum dan sesudah perlakuan.

Jumlah nilai kreativitas mahasiswa sebelum dan sesudah mengikuti program komunitas entrepreneur dapat dilihat pada Tabel 6.

Tabel 6. Nilai kreativitas mahasiswa sebelum dan Perlakuan

\begin{tabular}{llcc}
\hline & & Kreatif_Sebelum & Kreatif_Sesudah \\
\hline $\mathrm{N}$ & Valid & 75 & 75 \\
Sum & Missing & 0 & 0 \\
\hline
\end{tabular}

Berdasarkan Tabel 6, jumlah nilai skor kreativitas sebelum perlakukan yaitu sebesar 262, sehingga jika dirata-ratakan sebesar 3,49 skor. Dan ketika mendapatkan perlakukan, nilai skor kreativitas mahasiswa mengalami peningkatan yaitu naik sebesar 311, jika dirata-ratakan sebesar 4,15 skor. 
Esy Nur Aisyah

Tabel 7. Hasil Skor Kreativitas

\begin{tabular}{llcccc}
\hline No & Uraian & $\begin{array}{c}\text { Skor Kreativitas } \\
\text { Mahasiswa }\end{array}$ & $\begin{array}{c}\text { Skor } \\
\text { Maksimal }\end{array}$ & $\begin{array}{c}\text { Interval } \\
\text { Nilai Skor }\end{array}$ & Hasil \\
\hline 1 & $\begin{array}{l}\text { Sebelum } \\
\text { Perlakukan }\end{array}$ & 262 & 375 & $70 \%$ & Sedang \\
2 & $\begin{array}{l}\text { Setelah } \\
\text { Perlakukan }\end{array}$ & 311 & & $83 \%$ & Tinggi \\
\hline
\end{tabular}

Hasil nilai berdasarkan interval nilai skor di Tabel 7, menunjukkan tingkat kreativitas mahasiswa sebelum mendapatkan perlakuan adalah sedang. Akan tetapi setelah mendapatkan perlakukan yaitu tinggi. Perlakukan di sini maksudnya adalah mahasiswa mengukuti program komunitas entrepreuner. Hasil ini telah menjawab hipotesis kedua dalam penelitian, yaitu terdapat peningkatan keretivitas mahasiswa setelah mendapatkan perlakukan Project-Based Learning melalui Program Komunitas Entrepreneur.

Sebuah fenomena yang cukup menarik untuk dikaji, dimana terdapat peningkatan kreativitas setelah mendapatkan perlakuan dengan pembelajaran berbasis proyek melalui program komunitas entrepreneur. Mahasiswa yang tergabung di dalam komunitas entrepreneur dapat menggali wawasan dan mengimplementasikan gasagan atau ide yang mereka miliki dan sharing pengalaman dengan anggota yang lain. Penekanan model pembelajaran di sini adalah pada aktivitas mahasiswa yang bekerja secara mandiri atapun berkelompok dalam menemukan solusi dengan cara mengimplementasikan keterampilan yang dimiliki dalam meneliti, menganalisis, dan mengidentifikasikan produk pembelajaran atas pengalaman yang dialami.

Terjadinya perbedaan tingkat kreativitas tersebut bisa terjadi selain karena faktor keunikan dari masing-masing mahasiswa dalam menghasilkan ide dan produk yang inovatif, juga karena faktor proses yang dilalui mahasiswa. Dalam pembelajaran berbasis proyek mahasiswa bebas dalam mengekpresikan dirinya dengan lebih kreatif. Sedangkan tugas fasilitator/pendidik adalah membimbing dan sharing informasi untuk memberikan stimulus kepada mahasiswa agar selalu terlibat dalam berbagai program kreativitas. Suharta dan Luthan (2013) menyatakan bahwa kreativitas tidak akan muncul secara tiba-tiba/instan, namun membutuhkan sebuah proses dalam alur berpikir. Berpikir kreatif sering kali berawal

58| IQTISHODUNA Vol. 17 (1), 2021

http://ejournal.uin-malang.ac.id/index.php/ekonomi 
karena rasa keingintahuan yang mendalam dan disertai adanya kebutuhan untuk menemukan sebuah solusi.

Inovasi dan sarana pembelajaran adalah bagian yang cukup urgent untuk diamati dan dikaji. Bahkan inovasi pembelajaran dengan mengintegrasikan pada pendidikan karakter dapat memberikan peluang dalam meningkatkan mutu pendidikan (Situmorang et al., 2013). Kondisi mahasiswa saat ini adalah pelajar yang kritis dan aktif. Oleh karena itu, saat ini sudah tidak bisa lagi mengaplikasikan model pembelajaran konvensional, dimana metode edukasi berpusat pada dosen (Suharta dan Luthan, 2013). Sehingga membutuhkan nuansa baru di dalam aktivitas pembelajaran khususnya di bidang kewirausahaan yang diharapkan mampu secara teori dan praktik. Oleh karena itu, Project-Based Learning menjadi salah satu inovasi pembelajaran yang diharapkan mampu meningkatkan kreativitas dan kompetensi mahasiswa.

Pembelajaran Berbasis Proyek yang dilalui oleh mahasiswa konsentrasi entrepreneur merupakan proses pembelajaran yang terintegrasi dengan berbagai program pembelajaran, baik yang termuat di dalam kurikukum dalam bentuk matakuliah ataupun di Program Komunitas Entrepreneur. Kurikulum yang ditetapkan di Prodi Perbankan Syariah Fakultas Ekonomi UIN Maulana Malik Ibrahim Malang adalah seluruh mahasiswa harus menempuh matakuliah kewirausahaan. Pada matakuliah ini diharapkan mahasiswa sudah memiliki perubahan mindset untuk memiliki sifar seorang entrepreneur yakni percaya diri, berani mengambil risiko, kreatif, inovatif, kepemimpinan, dan kerja sama. Kemudian terdapat matakuliah utama bagi minat entrepreneur yang menjadi pilar utama di dalam desain pembelajaran ini yaitu matakuliah kewirausahaan, manajemen strategi, bisnis plan, studi kelayakan bisnis, dan seminar bisnis plan. Dan setelah mahasiswa sudah menempuh seluruh matakuliah tersebut, maka mahasiswa wajib merealisasikan rencana bisnisnya secara nyata dengan bekal ilmu dan pengalaman yang sudah diperoleh melalui pembelajaran di kelas dan di program komunitas entrepereneur. Selain itu untuk menunjang penguatan permodalan, mahasiswa entrepreneur diberikan akses pembiayaan pada laboratorium perbankan syariah berbasis transaksi riil yaitu di El Dinar Finance House. Sinergitas dari berbagai program yang dimiliki prodi Perbank Syariah diharapkan mampu memberikan nilai tambah pada mahasiswa, khususnya pada kreatifitas wirausaha mahasiswa. 
Esy Nur Aisyah

Potensi kreativitas sejatinya dimiliki oleh semua orang. Terdapat alasan mengapa kewirausahaan sangat berkorelasi dengan sifat kreatif dan inovatif yakni karena core utama dari kewirausahaan adalah kompentensi di dalam menciptakan sesuatu yang berbeda dan baru dan membuat peluang dengan cara bertindak inovatif dan berpikir kreatif (Suryana, 2011). Seseorang yang memiliki kecerdasan kreatif akan memiliki sifat terbuka, berani, revolusioner inovatif, spontan, berjiwa bebas, imajinatif, inventif, tak terduga, fantasis, dan tak terbatas (Susiana, 2005). Sifat-sifat tersebut adalah sifat-sifat yang melekat pada wirausahawan.

Pengembangan kreativitas peserta didik dapat dilakukan oleh pendidik dengan pengajaran yang kreatif. Torrance dalam Fasco (2001) mengatakan bahwa pengajaran kreatif bertujuan untuk mewujudkan lingkungan yang bertanggungjawab yang ditunjukkan dengan rasa antusiasise yang tinggi dari pendidik, apresisasi terhadap perbedaan individu, dan lain sebagainya. Davis (1991) menyebutkan beberapa cara untuk menciptakan lingkungan kelas yang konduktif untuk berpikir kreatif dengan: (1) mendukung dan memperluas ide dan tanggapan yang tidak lazim dari peserta didik. (2). Menggunakan kegagalan menjadi hal yang positif untuk membantu peserta didik belajar dari kesalahan serta memenuhi standar yang dapat diterima secara suportif. (3). Penyesuaian dengan ide dan minat peserta didik di kelas jika memungkinkan. (4). Memberikan waktu kepada peserta didik untuk memikirkan dan mengembangkan gagasan kreatif yang mereka miliki. Karena tidak semua kreativitas dapat terjadi secara cepat dan spontan. (5). Mewujudkan budaya saling menghormati dan menerima antara peserta didik dan pendidik sehingga peserta didik bisa berbagi, mengembangkan, dan belajar bersama dan dari satu sama lainnya dapat belajar secara mandiri. (6). Menyadari bahwa banyak jenis kreativitas, yakni selain seni dan kerajinan terdapat pula tanggapan verbal, tanggapan tertulis. Dan keduanya dalam gaya prosa dan puisi, fiksi, dan non fiksi. Kreativitas dapat masuk ke segala bidang dan disiplin kurikulum. (7). Mendukung kegiatan belajar yang tidak lazim. (8). Mendengarkan dan tertawa bersama peserta didik. Suasana yang hangat dan mendukung dapat memberikan kebebasan dan keamanan dalam mengeksplor pikiran. (9). Membiarkan peserta didik menjadi bagian dari proses pengambilan keputusan dan penentuan pilihan. Kita mengambil bagian dalam kontrol atas pendidikan dan pengalaman belajar mereka. (10). Membiarkan semua orang menjadi tersinggung, dan terlibat dengan mensupport gagasan peserta didik dan menjadi solusi atas masalah dan proyek mereka.

60 | IQTISHODUNA Vol. 17 (1), 2021

http://ejournal.uin-malang.ac.id/index.php/ekonomi 


\section{Implikasi Penelitian}

Implimentasi dari hasil penelitian ini adalah diketahui bahwa model pembelajaran berbasis proyek (Project-Based Learning) yang diterapkan di Program Komunitas Entrepreneur dapat meningkatkan kreativitas wirausaha mahasiswa. Hal ini memberikan sebuah bukti dalam perubahan paradigma pembelajaran. Terjadinya peningkatan kreatifitas yang siginifikan setelah mendapatkan metode pembelajaran berbasis proyek di dalam Program Komunitas Entrepreneur menunjukkan bahwa model ini efektif untuk dapat digunakan dalam meningkatkan kreativitas mahasiwa dalam berwirausaha. Banyak permasalahan yang dapat dijadikan sebagai bahan di Perguruan Tinggi, seperti masalah lingkungan, produk sehari-hari, UMKM di sekitar kampus, dan lain sebagainya. Karena Program Komunitas Entrepreneur merupakan wadah bagi mahasiswa untuk selalu berproses dalam mewujudkan dan mengimplementasikan ide dan proyek bisnisnya.

Bagi wirausahawan, kreativitas menjadi modal penting di dalam mengoperasionalkan bisnis. Oleh karena itu, peningkatan kreativitas melalui pembelajaran secara praktik dengan berbasis proyek akan membuat proses kegiatan belajar lebih matang baik dari sisi intelektualitas, emosional, dan sosial. Harmonisasi interaksi antara fasilitator/pendidik dengan peserta didik/mahasiswa di dalam proses pembelajaran dapat menghadirkan situasi yang nyaman dan menyenangkan, sehingga menumbuhkan semangat untuk lebih berkarya, berkreasi, dan berinovasi. Dan tentunya di dalam hal ini pendidik yang profesional dan kreatif sangat menjamin keberhasilan capaian pembelajaran yang bermutu tinggi

\section{Kesimpulan}

Berdasarkan hasil penelitian dan pembahasan, maka kesimpulan dari penelitian ini adalah terdapat perbedaan tingkat kreativitas mahasiswa sebelum dan sesudah mendapatkan perlakuan. Perlakuan di sini maksudnya adalah mahasiswa mengukuti program komunitas entrepreuner dengan pembelajaran berbasis Proyek (Project-Based Learning). Terdapat peningkatan kreativitas mahasiswa dari 70\% menjadi 83\%. Tingkat kreativitas mahasiswa sebelum mendapatkan perlakuan dalam kategori sedang. Dan setelah mendapatkan perlakukan yaitu berada dalam kategori tinggi. Dengan demikian, model pembelajaran berbasis proyek melalui Program Komunitas Entrepreneur di Prodi Perbankan Syariah Fakultas Ekonomi mampu meningkatkan kreativitas wirausaha mahasiswa. 


\section{Ucapan Terima Kasih}

Saya selaku peneliti mengucapkan terima kasih banyak kepada UIN Maulana Malik Ibrahim Malang melalui pembiayaan penelitian di LP2M yang telah memfasilitasi kegiatan ini, sehingga kegiatan ini dapat terlaksana dengan baik.

\section{Daftar Pustaka}

Aisyah, E. N., \& Solekah, N. A. (2018). Model Pembiayaan Mikro Pada Mahasiswa Berbasis Entrepreneurship. In Prosiding Seminar Nasional: Manajemen, Akuntansi, dan Perbankan, 1(1), 990-1002.

Al-Tabany, Trianto Ibnu Badar. (2014). Mendesain Model Pembelajaran Inovatif, Progresif, Dan Kontekstual: Konsep, Landasan, Implementasinya pada Kurikulum 2013(Kurikulum Tematik Integratif/KTI). Jakarta: Kencana.

Ananta, R. K. E., \& Farid, M. (2014). Minat Wirausaha, Konsep Diri dan Kreativitas. Jurnal Psikologi Tabularasa, 9(1), 48-57.

Aqib, Z. (2013). Model-Model, Media dan Strategi Pembelajaran Kontekstual (Inovatif). Bandung: CV Yrama Widya.

Davis, G. A., (1991). Teaching Creativity Thinking In Handbook of Gifted Education, Boston, Allyn and Bacon.

Delobelle, V. (2008). Corporate Community Management. Diambil dari http://www.vaninadelobelle.com.

Fasco, Jr., D., (2001). Education and Creativity. Creativity Research Journal, $13(3 \& 4), 317-327$.

Harianti, A., \& Margaretha, Y. (2014). Pengembangan Kreativitas Mahasiswa dengan Menggunakan Metode Brainstorming dalam Mata Kuliah Kewirausahaan. Jurnal Manajemen Maranatha, 13(2), 175-192.

Hasanah, M., \& Ratumbuysang, M. F. N. (2017). Strategi Peningkatan Minat Wirausaha Mahasiswa Melalui Program Kreativitas MahasiswaKewirausahaan (PKM-K) di Program Studi Pendidikan Ekonomi FKIP Universitas Lambung Mangkurat. Jurnal Socius, 6(02), 294-313.

Johnson, E. B. (2007). Contextual teaching and learning: Menjadikan kegiatan belajar mengajar mengasyikkan dan bermakna. Bandung: Mizan

62| IQTISHODUNA Vol. 17 (1), 2021

http://ejournal.uin-malang.ac.id/index.php/ekonomi 
Learning Center.

Kasali, Rhenald et al. (2010). Manual untuk Instruktur: Kewirausahaan untuk Program Srata 1. Yayasan Rumah Perubahan bekerjasama dengan Bank Mandiri, Indonesia.

Kertajaya, H. (2008). Arti komunitas. Jakarta: Gramedia Pustaka Utama.

Kurniati, E. D. (2015). Kewirausahaan industri. Deepublish.

Margaretha, Y; Harianti, A; Lisan, H. (2012). Analisis Perbedaan Tingkat Kreativitas Mahasiswa Sebelum dan Sesudah diberi Pengajaran Kewirausahaan. Fakultas Ekonomi Universitas Kristen aranatha, Bandung.

Pamilu, A. (2007). Mengembangkan kreativitas dan kecerdasan anak. Yogyakarta: Citra Media.

Riduwan dan Kuncoro A. E. (2008). Cara Menggunakan dan Memakai Analisis Jalur. Bandung: Alfabeta.

Sari, R. T., \& Angreni, S. (2018). Penerapan Model Pembelajaran Project Based Learning (PjBL) Upaya Peningkatan Kreativitas Mahasiswa. Jurnal Varidika, 30(1), 79-83.

Setyawati, E. (2019). Analisis Kreativitas dan Produktivitas Mahasiswa pada Matakuliah Kewirausahaan (Studi Kasus Mahasiswa STKIP PGRI Pacitan). Jurnal Penelitian Pendidikan, 11(1), 1586-1594.

Situmorang, M., Simatupang, N., dan Silaban, R. (2013). Pengembangan Buku Ajar Kimia Inovatif Untuk SMA/MA Kelas X Semester II, Jurnal Pendidikan Kimia, 5(2), 129-131.

Suharta dan Luthan,P. L. A. (2013). Application Of Cooperative ProblemBased Learning Model To Developcreativity And Foster Democracy, And Improve Student Leaning Outcomes Inchemistry In High Scool. Journal Of Education And Practice, 4, 55-60.

Sumarno, S., Gimin, G., Haryana, G., \& Saryono, S. (2018). Desain pendidikan kewirausahaan mahasiswa berbasis technopreneurship. Jurnal Ekonomi Pendidikan dan Kewirausahaan, 6(2), 171-186.

Suryana. (2011). Kewirausahaan Pendoman Praktis: Kiat dan Proses Menuju Sukses. Jakarta: Salemba Empat. 
Esy Nur Aisyah

Susiana, N. (2005). Program Pembelajaran Kimia Untuk Menumbuhkan Sikap Wirausaha Siswa SMA. Jakarta: Universitas Pelita Harapan.

64| IQTISHODUNA Vol. 17 (1), 2021

http://ejournal.uin-malang.ac.id/index.php/ekonomi 